\title{
Mobile Payment: The Next Frontier of Payment Systems? - An Empirical Study Based on Push-Pull-Mooring Framework
}

\section{Liu Fan ${ }^{1}$, Xiaoping Zhang ${ }^{2}$, Laxmisha Rai ${ }^{3}$ and Yuanwei $\mathrm{Du}^{4}$}

1 Ocean University of China, Management College, Qingdao, China, imfanliu@163.com

2 Shandong University of Science and Technology, College of Economics and Management, Qingdao, China, 17854259370@163.com

${ }^{3}$ Shandong University of Science and Technology, College of Electronic and Information Engineering, Qingdao, China, laxmisha@ieee.org

${ }^{4}$ Ocean University of China, Management College, Qingdao, China, duyuanwei_ouc@163.com

${ }^{*}$ Corresponding author: Yuanwei Du

Received 18 December 2019; received in revised form 13 June 2020; accepted 24 July 2020

\section{Abstract}

Push-Pull-Mooring framework is adopted to identify the antecedents affecting users' switching intention from Internet payment to mobile payment. Using the data obtained from 264 valid respondents, the results show that both the mooring factors (perceived switching cost and personal innovativeness) and pull factors (relative advantages of substitute information technology and critical mass) are direct antecedents affecting customer switching behavior. In addition, mooring factors could moderate the relationship between push factors (dissatisfaction on system quality and dissatisfaction on service quality) as well as pull factors and customer switching intention. Managerial implications of findings were provided to payment service providers for maintaining incumbent customers and attracting potential customers.

Keywords: Mobile payment, Internet payment, Push-pull-mooring framework, Switching intention, Structural equation modeling

Liu Fan Xiaoping Zhang Laxmisha Rai Yuanwei Du 


\section{Introduction}

Recently, the prevalent usage of mobile devices among vast majority of online users has resulted in the dramatic increase of mobile commerce (m-commerce) [70]. As one of the most representative application of m-commerce, mobile payment (m-payment) is regarded as a critical driver to boost its successful development [74]. M-payment refers to the use of wireless communication and mobile devices to enable the purchase of services and goods and to provide users with fast convenience, independence, mobility and flexibility [7], [41], [65]. Beyond the capability of supporting both online and proximity-based transactions, m-payment methods have direct benefits for both merchants and consumers [36]. For merchants, m-payment services promise an increased transaction volume, customer loyalty and decreased transaction cost [36]. And for consumers, m-payment services could provide an enjoyable purchasing experience that is secure, fast and convenient [36].

Attracted by the strong potential of m-payment, numerous firms have launched or updated m-payment applications to strive for prominence and huge profits (such as Alipay, Boku, and Paypal), and some of them even transferred their current services from Internet based to mobile based services [52]. However, the m-payment adoption does not increase globally despite its enhanced security and convenience [36]. China takes a lead with m-payment usage rate reaching $74.6 \%$ in 2017 and Internet payment remaining only $25.4 \%$, while only $38 \%$ of US population show the willingness to use m-payment, and $74 \%$ still take Internet payment as their preference [59]. In Middle East, only $1 \%$ population would like to use m-payment [59], indicating more efforts for promotion of $\mathrm{m}$-payment is still necessary. According to Lu et al. [52], Internet payment highlights the payment process with the use of PC (Personal Computer), while m-payment puts more emphasis on the use of mobile devices (such as mobile phone, smartphone) requiring the use of mobile network [17], [47], [60]. Although m-payment provides customers with an even safer and easier payment process [40], the imbalanced situation in the whole world shows a reminder for $\mathrm{m}$-payment applications - it is still important to effectively appeal the users who are still locked in Internet payment to m-payment.

However, extant studies on m-payment mainly focused on users' adoption/acceptance, and continuance usage intention [8], [25], [39], [48]. Little attention was paid to the factors that drive users to switch from incumbent payment method to m-payment. Essentially, internal beliefs and external stimuli that users hold to guide their adoption and continuance usage intention might not be employed to explain the switch [8], [24], [25], [39], [48], [54], since the switching behavior reflects the best choice after comparing the characteristics of different systems [21]. Currently, users' switching behaviors have been examined in various contexts including e-health care services [44], online auctions [50], mobile shopping [43], and blog services [32], but the distinct characteristics of m-payment may challenge the results derived from other research settings.

Hence, a model of switching behavior from Internet payment to m-payment was established and examined based on push-pull-mooring (PPM) framework in this study. PPM framework serves as a theoretical basis to reveal the predictive factors of customers' switching behavior [9], [31], [43], including push factors that drive customers away from current services, pull factors that attract customers to new alternative, and mooring factors that either facilitate or block switching behavior [3].

The contributions of this paper are twofold. First, we address the gap of usage behavior for m-payment from the perspective of switching by extending the PPM framework to the context of $\mathrm{m}$-payment application. Second, we generate results to offer suggestions for m-payment service providers to attract potential users as well as to retain existing users. The reminder of this paper is organized as follows. Section 2 summarizes previous studies pertaining to switching behavior, m-payment, and PPM framework. Section 3 elaborates on the research model and hypotheses with detailed explanations. Section 4 elaborates the empirical methods and results. Finally, the discussions and conclusions are presented in Section 5 and 6 respectively.

\section{Literature Review}

In this section, the theoretical contributions in the field of mobile payment and customer switching behavior are described in order to highlight the gaps in the existing literature. Especially, relevant literature including advantages of mobile payment and related studies, customer switching behavior, push-pull-mooring framework related studies are presented as follows.

\subsection{Advantages of Mobile Payment and Related Studies}

M-payment is the payment method for goods, services, or bill invoices [41], [52] using mobile devices (such as a mobile phone, smart-phone, or personal digital assistant) and wireless communication technologies (such as mobile telecommunications networks, proximity technologies) [70], [78]. Compared with other payment methods, the mobility of $m$-payment service frees users from temporal and spatial constraints. The advantages of $m$-payment for customers and companies were discussed in numerous literature [36], [65]. For customers, key benefits include convenience, speed, mobility, and independence, while strengths such as increased transaction volumes, faster transactions, greater convenience, increased consumers loyalty and reduced transaction costs contribute to 
significant advantages for companies or vendors [7], [65]. Premised on that, m-payment is considered as a future star application with the greatest market potential in mobile communications discipline [49].

M-payment usage has attracted increasing attention from academic researchers. Among extant studies on $m$ payment usage, the mechanism of adoption/acceptance and continuous usage were frequently discussed [8], [25], [39], [48], [51], [60]. In these studies, Technology Acceptance Model (TAM) and Unified Theory of Acceptance and Use of Technology (UTAUT) model with additional variables were generally used, and several predictive factors of adoption and continuous usage intention, such as cost, system quality, perceived risk and demographics have been identified. However, the decision to accept m-payment is not made only with its advantages, but the result of comparison between the m-payment and the incumbent payment system in use. Thus, it is necessary to consider the antecedents that influence users' switching intention from the incumbent payment application to m-payment.

\subsection{Customer Switching Behavior}

Customer switching behavior generally refers to customers' transfer between service providers or firms [31], which emphasizes on the main usage related to post-behavior based on the comparison. Users' switching intention in this paper is defined as the behavioral intention of replacing an incumbent payment application with an alternative. Previous research demonstrated that switching behavior between different products or services could affect enterprise competitiveness and long-term survival [21], [32], [43], [44], [50]. The research on customer switching behavior has been one of the intrusive domain in marketing, and it was frequently predicted by switching intention in academic literature. So far, switching behavior and its antecedents in online context, such as e-mails, blog services, and online games have been explored [42], [72], [77]. Relative antecedents can be briefly summarized into two aspects: (1) factors related to service or product, such as information quality, system quality, service quality, availability of alternative attractiveness, and switching costs [21], [31], [37], [57]; and (2) factors related to users, such as satisfaction, habit, and customer characteristics [18], [72], [77].

However, the distinctive characteristics of m-payment may challenge above results in typical research settings, as $m$ payment discloses highly personal information, and requires complicated set-up and involved process [70]. Due to the unique characteristics of m-payment application, researchers have paid more attention to users' switching intention or behavior of m-payment application. For instance, some studies have investigated how product-based factors influence switching intention. In particular, Wang et al. [70] argue that privacy concerns can be a key factor that challenges the development of m-payment, and users might switch to alternative payment application if they perceive that the incumbent vendor fails to protect their personal information. Researchers have also found monetary rewards to influence users' switching behavior of m-payment application, stating that users are more likely to switch to alternatives that grant them with monetary rewards [64]. Additionally, scholars also examine the influence of personal perception-based factors, such as satisfaction [70], trust [26, 80], inertia [27], [67], and flow [80] on users' intention to switch to m-payment. For instance, Gong et al. [27] confirm that users experiencing inertia tend to persist in using incumbent web payment and hesitate to switch to new m-payment application. Based on status quo bias theory and coping theory, they also find that perceived value and perceived controllability to mobile payment increase users' intention to switch to mobile payment from web payment, but perceived threat decreases the intention. Gong et al. [26] suggest that both users' cognitive trust and users' emotional trust in m-payment increase the intention to switch to mobile payment application. Zhou [80] argues that when users obtain flow, they feel great enjoyment and tend to be immersed in using mobile payment. As a result, this might drive users' switch to mobile payment. However, most of them examine the switching intention or behavior from the perspective of the perception of $\mathrm{m}$-payment service. Generally, users tend to compare the m-payment with the incumbent payment system that they are using before making a switching decision. But little attention is paid to how the perception of incumbent service influence users' intention to switch. Meanwhile, it is unclear whether there are moderating variables that drive or hinder users' intention to switch. Therefore, based on PPM model, this study attempts to investigate the intention to switch to m-payment from three aspects, push factors forcing users to be away from incumbent payment services, pull factors attracting users to m-payment services, and mooring factors either encouraging or hindering switching behavior.

\subsection{Push-Pull-Mooring Framework Related Studies}

The research related to PPM framework can be dated back to 1885 [63]. It comprehensively describes that individual's migrating decision from an original place to a new one in a certain period is affected by push, pull and mooring factors [3]. Push factors, often referred to as stressors denoting the negative factors that drive people away from the original place [3], such as decline in a natural resource, loss of employment, and lack of opportunities for personal development [6]. Pull factors, often mentioned as attractors, which are the positive factors that destination offers to people [3], including superior employment opportunities, higher income or education, preferable environment, and opportunities for new activities [6]. Finally, mooring factors refer to the personal or social factors which decide either potential migrants to stay at the original place or facilitate them to move to a new destination [45], [58].

The PPM framework was selected to understand m-payment switching behavior in this study for two reasons. Firstly, PPM framework provides an insight to explain individual's migrating decision from one place to another in a certain 
period [3]. M-payment switching is defined as the behavior that results in users to shift from incumbent payment application to alternatives [70]. The analogy between m-payment users' switching behavior and human migration is straightforward and of theoretical relevance [70]. Secondly, PPM framework has also been extended to marketing domains to understand customer switching behaviors, such as MMORPGs [31], mobile shopping [43], social network sites [10]. It is expected that PPM framework could provide a new lens for explaining users' switching behavior in the context of payment application.

\section{Research Model and Hypothesis}

Taking PPM framework as the theoretical basis, potential factors influencing switching behavior from Internet payment to m-payment should be selected firstly. For push factors, satisfaction/dissatisfaction on current service was regarded as an important indicator for service adoption or continuous usage [18], [51], [61], [76]. While in information system context, performance of system, including system quality, service quality, and information quality, was the most vital predictors for users' satisfaction/dissatisfaction [19], [46]. Information quality mainly considers personalized, complete, relevant, easy to understand, and secure content [19], which are common to both Internet payment and mpayment. Thus, dissatisfaction on system quality and dissatisfaction on service quality were selected as the push factors that drive users away from incumbent payment services. For pull factors, alternative advantage is an important factor to attract customers switch from one technology to another [65]. And individuals who face a new choice would tend to imitate the behaviors of their peers [55], i.e., herd effect. Thus, relative advantages of substitute information technology (IT) and critical mass were selected as the pull factors. For mooring factors, various factors were investigated in previous research, such as switching cost, personal traits, and experience [13], [32]. In this paper, the switching cost and personal innovativeness were viewed as vital mooring factors, because for individuals who face with a new technology, switching cost is a critical barrier because it identifies an individual's sacrifice in psychological and even monetary aspect [38], while the personal innovativeness gives an initial motivation to use the m-payment.

Premised on that, the final research model was presented in Figure 1.

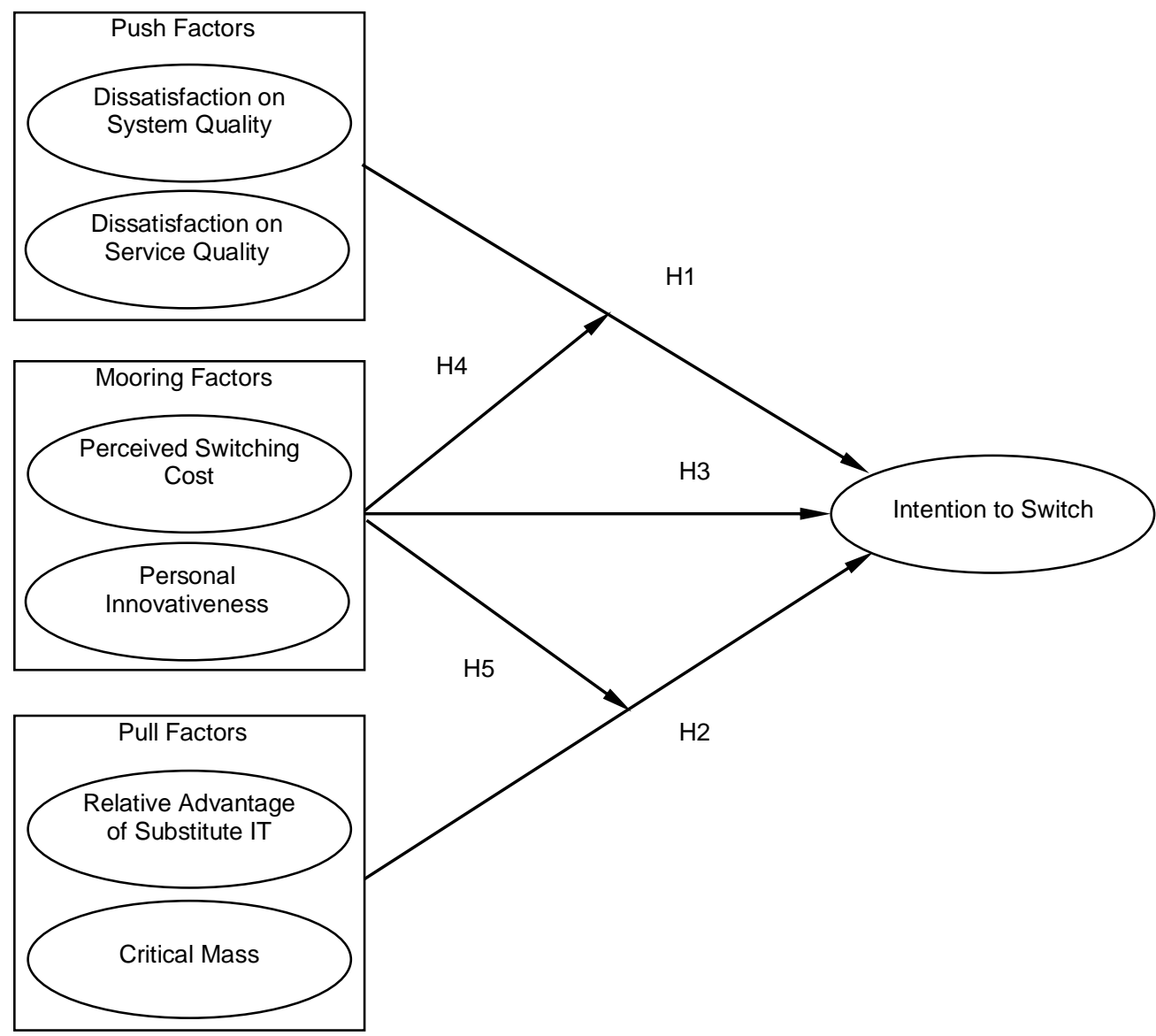

Figure 1: Research model 


\subsection{Push Factors}

This section attempts to hypothesize the relationship between push factors and users' intention to switch from Internet payment to m-payment. Push factors are operated as dissatisfaction with system quality and dissatisfaction with service quality.

\subsubsection{Dissatisfaction with System Quality}

System quality measures desired characteristics of an information system, including a user-friendly interface, ease of use, availability, system stability, and response time [19], [22]. A system with high system quality enables users to easily navigate on and conveniently find information they need [46]. On the contrary, a system with poor usefulness, usability and responsiveness excites users' impatience and anxiety. If m-payment service could supply a higher quality system for users than Internet payment system, where users could scan to pay by m-payment quickly, whereas they need to wait or sign for Internet payment system, they would like to perceive that the Internet payment system is fussier to operate. As a result, the intention to switch to m-payment will be increased. Thus, we suggest:

H1-1: Dissatisfaction with system quality positively affects the intention to switch from Internet payment to mpayment.

\subsubsection{Dissatisfaction with Service Quality}

Service quality is the overall support delivered by a service provider, which reflects reliability, responsiveness, assurance and personalization of information system [79]. Service quality affects users' trust, satisfaction, and willingness to stay with the current service [31], [42]. Service satisfaction is usually adopted to examine the degree of intention to stay with the incumbent service in both online and offline service contexts [31]. Unsatisfied customers usually have a higher switching intention than those satisfied ones, thus if a customer is not satisfied with a product or service, he/she will actively seek for an alternative [30]. In m-payment system, substantial functions that Internet payment cannot provide are integratively-embedded to facilitate user's comfort and increase the fun of use, such as some convenient external-chain services (e.g. taxi-hailing app, red packet or gift packet). Premised on that, we hypothesize that:

H1-2: Dissatisfaction with service quality positively affects the intention to switch from Internet payment to $m$ payment.

\subsection{Pull Factors}

This section explains how the pull factors influence users' intention to switch from Internet payment to m-payment. Pull factors are operated as relative advantage of substitute IT and critical mass.

\subsubsection{Relative Advantage of Substitute IT}

Referring to the human migration theory, attraction from another service influences customer's switching intention, which was also affirmed in the research of information systems [65]. M-payment provides customers with ubiquitous purchase possibilities, an alternative to cash payment and timely access to monetary assets [55]. Previous studies also demonstrated that users' switching intention is positively related to their level of perception of the alternatives' advantage [42]. Advantages of m-payment compared with Internet payment are likely to pertain to location and time independent purchase possibilities. Those advantages offer better experience for users, thus encouraging them to switch from Internet payment and switch to m-payment. We hypothesize that:

H2-1: Relative advantage of substitute IT positively affects the intention to switch from Internet payment to mpayment.

\subsubsection{Critical Mass}

Critical mass refers to "a small segment of the population makes big contribution to the collective action while the majority does little or nothing" [10]. Critical mass reflects the extent that an individual believes the behavior happens to a significant number of people. It emphasizes that individuals actively imitate the behaviors that occur among other people who are important to them. Evidence shows that the peers' behavior has a strong effect on churn, or leaving a service provider of other customers [20]. Peer influence has a vital effect on affecting users' behaviors of adopting a new technology [33], [69]. Users' decision to use a payment application is thus influenced by the other users and merchants [76]. Currently, critical mass has been generally applied to examine the influence on adoption of media, such as blogs, email, Twitter, and Facebook [62]. If most friends of a potential user use m-payment, the latter would probably develop switching intention to avoid being in a minority. Thus, hypothesis is followed:

H2-2: Critical mass positively affects the intention to switch from Internet payment to m-payment. 


\title{
3.3 Mooring Factors
}

This section explores how mooring factors including perceived switching cost and personal innovativeness moderate the relationship between push factors and the intention to switch. Similarly, the relationship between pull factors and the intention to switch are also described.

\subsubsection{Perceived Switching Cost}

Migrating costs play a great role in migrating decision. Migrants might quit the migrating intention because of the high cost. Similar to migration from original residence to a new destination, previous research in marketing also highlighted that switching cost decreased customer's defection [5], [70]. Switching costs are the penalties or sacrifices including not only monetary damages but also psychological costs originating from the service transition [37], which makes it difficult for users to switch from incumbent services to others [38]. When customers perceive high switching cost, they usually voluntarily tend to locked in to the current service provider [3], [12]. During the process of switching to m-payment service, two kinds of switching cost are equally inevitable: monetary costs, such as mobile equipment cost, transaction fee, and access cost; and non-monetary costs, such as uncertainty and possible loss related to adoption decision [32], [52], [73], [74]. If users have to undertake high switching costs for $\mathrm{m}$ payment service, they probably prefer to stay at the relatively cheaper Internet payment. Thus, we posit hypothesis below:

\section{H3-1: Perceived switching cost negatively affects the intention to switch from Internet payment to m-payment}

\subsubsection{Personal Innovativeness}

Personal innovativeness refers to the degree of how individuals accept new ideas, make innovative decisions or endeavor to try new things [56]. General innovation diffusion theory recognizes that highly innovative individuals are more active in new information seeking, more capable of coping with high-level of uncertainty and perform a higher likelihood to develop positive attitudes or intentions towards innovation than those with less innovativeness [35], [66], [67]. Jackson et al [35] has also found the effectiveness of personal innovativeness on customers' decision to accept a technology. As a new payment method, m-payment needs to be objectively recognized, especially under the circumstance of numerous news related to potential safety hazards. It might be easier for users with high innovativeness to use m-payment, because they have stronger abilities to understand this new payment and cope with risks. Thus, we propose:

\section{H3-2: Personal innovativeness positively affects the intention to switch from Internet payment to m-payment.}

\subsection{Moderation Effect of Mooring Factors}

Mooring factors are regarded as intervening obstacles. Individuals may not shift to a new choice under the effects of mooring factors, even under strong influences of push or pull factors [3].

\begin{abstract}
Switching cost is thought as an evident factor that remains users' relationships [37]. In the process of technology switching, even when monetary cost may not be involved, there are at least procedural costs during the switch [75]. A study by He and Reiner [29] found that customers may tolerate the incumbent products or services when switching cost is perceived as high. Thus, switching cost could be an obstacle to users' switching behavior even if they are regretful and dissatisfied with their current application [9]. Although individuals were dissatisfied with the system quality of Internet payment, like they thought it is more convenient to pay by scanning the QR code embedded in $\mathrm{m}$ payment, the switching behavior will be blocked as they have to bear extra cost such as wireless Internet fee or potential risks. Additionally, if individuals perceive the advantages of $\mathrm{m}$-payment, such as the convenience without spatial or temporal limitation, threshold of switching cost would remind them of considering their actual paying ability or risk tolerance for m-payment. Also, even individuals were surrounded by various m-payment users, switching cost would be a core factor to determine the intensity of passion on $\mathrm{m}$-payment usage. That is, if a user perceives switching cost as high, it is less likely that he/she will switch regardless of perceptions he/she holds on the two services or products [75].
\end{abstract}

Thus, we hypothesize:

H4-1: Perceived switching cost negatively moderates the relationship between dissatisfaction with system quality and intention to switch.

H4-2: Perceived switching cost negatively moderates the relationship between dissatisfaction with service quality and intention to switch.

H4-3: Perceived switching cost negatively moderates the relationship between relative advantage of substitute IT and intention to switch. 
H4-4: Perceived switching cost negatively moderates the relationship between critical mass and intention to switch.

Individuals with higher innovation skills are thought to have a higher tendency to accept new products or technologies. Highly-innovative members are receptive to changes, inclined to see the potential of an innovation as in accordance with their objectives [35], and are less anxious about new technologies [67]. In addition to acting as a direct antecedent, personal innovativeness has been demonstrated as a moderator in IS studies. These studies usually involve perception, attitude or behavioral intention. For instance, Tan and Sie [67] found that personal innovativeness strengthened the positive relationship between satisfaction and self-brand connection. Chen and Chen [11] successfully showed that personal innovativeness facilitated the relationship between attitude and behavioral intention. Tsou [68] revealed that high personal innovativeness could strengthen the relationship between attitude and adoption intention towards Office 2010 and Windows 7. In summary, personal innovativeness could be regarded as a driving factor that increases the users' switching intention. In this regard, following hypotheses are proposed:

H5-1: Personal innovativeness positively moderates the relationship between dissatisfaction with system quality and intention to switch.

H5-2: Personal innovativeness positively moderates the relationship between dissatisfaction with service quality and intention to switch.

H5-3: Personal Innovativeness positively moderates the relationship between relative advantage of substitute IT and intention to switch.

H5-4: Personal Innovativeness positively moderates the relationship between critical mass and intention to switch.

\section{Research Methods}

To affirm the effectiveness of the proposed model, a self-designed questionnaire is conducted to collect data. The Structural Equation Modeling (SEM) analysis with AMOS 7.0 is used to test the conceptual framework. The instrument development and measurement, data collection, data analysis and results are presented in this section.

\subsection{Instrument Development and Measurement}

The survey instrument is developed through three steps. Firstly, a draft of a multi-item questionnaire referring to the previous literature was formed. For the push factors, both of dissatisfaction with system quality and dissatisfaction with service quality were referred to Chiu et al. [16] For pull factors, relative advantage of substitute IT was referred to Lu et al. [52], while critical mass was designed from the research of Luo et al. [53]. And for the mooring factors, switching cost was formed referring to Jones et al.[37], and personal innovativeness was acquired from Agarwal \& Prasad [1]. Finally, for intention to switch, items were established with respect to Fan \& Suh [21]. Items are slightly modified to fit the research context, and all of them are measured with five-point Likert scales, ranging from disagree strongly (1) through neutral (3) to agree strongly (5). Secondly, advice from academics and technology developers were collected to revise the questionnaire. Then, minor adjustments were made to few items based on a pilot test. For example, we deleted the items with general descriptions in dissatisfaction with system quality and service quality - To what extent are you dissatisfied with the system/service quality of Internet payment?, and changed them to specific items related to the characteristics of Internet payment system - Compared to m-payment, the work stability of Internet payment is weaker, and Internet payment cannot provide qualified service that I need. Finally, 28 items for 7 constructs were reserved. For push factors, both dissatisfaction with system quality and service quality were measured by five items respectively (SYQ1-5 \& SEQ1-5). For pull factors, relative advantage of substitute IT was tested by four items (RA1-4), and critical mass by three (CM1-3). For mooring factors, perceived switching cost was measured by four items (SC1-4), personal innovativeness by four (PI1-4). And dependent variable - intention to switch - was consisted of three items (IS1-3).

\subsection{Data Collection}

As the present study focuses on switching intention from Internet payment to m-payment, samples that indicating the use of Internet payment and experience or knowledge of $\mathrm{m}$-payment initially in China were selected. The definition of Internet payment and m-payment were informed to participants before answering the questionnaire. Individuals taking Internet payment as their main payment application were directed to answer the questionnaire. To increase the reliability and validity of the results, the questionnaires took special care of the variety of the occupations of respondents, which, include civil servants, business employees, freelances, and students. Considering the features of respondents, questionnaire distribution is exercised based on the field survey. In order to improve the efficiency, we established the online version using a popular questionnaire design site in China in advance for questionnaire distribution, with participants directed to the homepage of this questionnaire by an online link. Participants filled out the questionnaire without any monetary compensation voluntarily. Respondents can choose the format of paper or electronic version to finish the questionnaire according to their reading preferences. Considering the basic scheme of 
our survey, which is based on the field survey, there is no difference between those respondents. Respondents were firstly asked whether they have used Internet payment and experienced m-payment at least once or not; if positive answer was obtained, he/she will be asked to participate in the survey.

Data were gathered with 280 respondents, of which 16 questionnaires obviously excluded for lack of serious response. Specially, $54.55 \%$ of the participants aged $20-30,31.82 \%$ aged $31-40,9.85 \%$ aged $41-50,2.27 \%$ aged $51-60$, and $1.52 \%$ aged above 60 . There was a smaller number of males $(34.09 \%)$ than females $(65.91 \%)$. Regarding their occupations, $43.18 \%$ of the participants were students, $9.47 \%$ were business employees, $16.29 \%$ were civil servants, $7.58 \%$ were professionals, and the rest were distributed in other fields. The educational level of participants is: $11.74 \%$ with junior and below, $57.20 \%$ with bachelor's degree, $28.41 \%$ with master's degree and $2.65 \%$ with doctor's degree.

\subsection{Data Analysis and Results}

To test the hypotheses, this study uses a two-stage methodology in which the measurement model and structural model are developed and evaluated separately. Firstly, the main purpose of confirmatory factor analysis to establish the convergent and discriminant validity of the constructs is described. Secondly, details of structural equation modeling which performed to test the causalities in the proposed model is shown.

\subsubsection{Measurement Model}

Firstly, confirmatory factor analysis was carried out using AMOS 7.0 to test the convergent validity of seven constructs. According to the criteria of the factor loading offered by Hair et al. [28] that all items should load more than $0.6(p<0.05)$ on their related factors, SYQ4, SEQ3, PI3, and CM2 are deleted. Among reserved 24 items, the value of standardized factor loading to its related construct ranges from 0.704 to $0.943(p<0.001)$, as shown in Appendix A. The data shows high convergent validity.

Secondly, composite reliability (CR) and average variance extracted (AVE) are calculated to test the reliability. From Appendix A, all CR exceed the threshold of 0.7[28], and the AVE of each construct is higher than the acceptance value of 0.5 proposed by Fornell \& Larcker [23], indicating reliability meets the requirement.

Finally, the correlations between the constructs are compared with square roots of AVE to test discriminant validity. As shown in Table 1, square roots of AVE are all higher than its correlations with other constructs, i.e., discriminant validity of the measurement model is adequate.

Table 1: Correlations and square roots of average variance extracted

\begin{tabular}{|l|l|l|l|l|l|l|l|}
\hline & RA & CM & SYQ & SEQ & SCT & PI & IS \\
\hline RA & .800 & & & & & & \\
\hline CM & .671 & .770 & & & & & \\
\hline SYQ & .689 & .589 & .841 & & & & \\
\hline SEQ & .542 & .480 & .675 & .790 & & & \\
\hline SCT & .392 & .379 & .441 & .543 & .827 & & \\
\hline PI & .367 & .332 & .375 & .352 & .245 & .928 & \\
\hline IS & .697 & .637 & .632 & .473 & .268 & .404 & .889 \\
\hline
\end{tabular}

Note: Values on the diagonal represent the square root of the AVE, and the other matrix entries indicate the correlations between each construct

\subsubsection{Structural Model}

The structural model is evaluated to test the goodness of fit of research model [4]. Results indicate that the chisquare of the structural model at 549.508 with d.f. of 231 , the ratio of chi-square to d.f. at 2.379 below the cut-off value of $3, \mathrm{GFI}$ at 0.854 above the cut-off value of $0.80, \mathrm{NFI}$ at 0.895 above the cut-off value of $0.85, \mathrm{CFI}$ at 0.935 above the cut-off value of 0.85 , TLI at 0.923 above the cut-off value of 0.9 , and RMSEA at 0.072 below the cut-off value of 0.08 are accepted [71]

Hypotheses are examined by structural equation modeling using AMOS 7.0. The results are presented in Table 2 and Table 3. Firstly, the main effect model shows that neither dissatisfaction with system quality or service quality has significant effect on perceived intention to switch; $\mathrm{H} 1$ is rejected. Relative advantage of substitute of IT and critical mass positively effects intention to switch respectively; $\mathrm{H} 2-1$ and $\mathrm{H} 2-2$ are supported. Switching cost negatively affects intention to switch, while personal innovativeness positively does; H3-1 and H3-2 are supported.

Secondly, the interaction model shows that perceived switching cost moderates the relationship between dissatisfaction with system quality and intention to switch, relative advantage of substitute IT and intention to switch, critical mass and intention to switch respectively; H4-1, H4-3 and H4-4 are supported. However, the moderating effects of perceived switching cost on dissatisfaction with service quality and intention to switch is not significant; $\mathrm{H} 4$ 2 is rejected. Personal innovativeness negatively moderates the relationship between dissatisfaction with system 
quality and intention to switch, dissatisfaction on service quality and intention to switch, relative advantage of substitute IT and intention to switch, critical mass and intention to switch respectively; H5-1, H5-2, H5-3, and H5-4 are reversely supported. In order to estimate and compare the moderating effects size further, squared multiple correlation $\left(R^{2}\right)$ of main model and four interaction models are compared. The effect size is evaluated by computing Cohen' $s f^{2}$ following the guideline of Chin et al. [14].

$$
\begin{aligned}
& \left.f^{2}=\left[R^{2}(\text { extended model })-R^{2} \text { (intiative model }\right)\right] / \\
& {\left[1-R^{2} \text { (intiative model) }\right]}
\end{aligned}
$$

Note: Results of equation indicate small, medium and high moderating effects respectively when $0.02<\mathrm{f}^{2}<0.15$, $0.15<\mathrm{f}^{2}<0.35$, and $\mathrm{f}^{2}>0.35$. Medium and high effects signifies that the resulting path coefficients are vital.

Based on the $f^{2}$ summarized in Table 2 , the moderating effects of perceived switching cost $\left(f^{2}=0.384\right)$ and personal innovativeness are remarkable $\left(f^{2}=0.746\right)$, and the latter one holds a more important role than formal one.

\begin{tabular}{|c|c|c|c|c|c|c|c|c|c|c|c|}
\hline \multicolumn{3}{|l|}{ Path } & \multirow{2}{*}{$\begin{array}{c}\begin{array}{c}\text { Main } \\
\text { Model }\end{array} \\
-0.003\end{array}$} & \multicolumn{2}{|c|}{ Interaction to SYQ } & \multicolumn{2}{|c|}{ Interaction to SEQ } & \multicolumn{2}{|c|}{ Interaction to $\mathrm{RA}$} & \multicolumn{2}{|c|}{ Interaction to $\mathrm{CM}$} \\
\hline SYQ & $-->$ & IS & & 0.488 & 0.623 & 0.1770 & 0.057 & 0.163 & 0.073 & 0.187 & 0.115 \\
\hline SEQ & $-->$ & IS & 0.275 & -0.140 & -0.208 & 0.087 & 0.261 & 0.034 & 0.079 & 0.048 & 0.078 \\
\hline SC & $->$ & IS & -0.123 & $\underset{* \star *}{0.166}$ & -0.039 & -0.088 & $\begin{array}{l}-0.116 \\
*\end{array}$ & 0.106 & -0.080 & -0.017 & $\begin{array}{l}-0.097 \\
*\end{array}$ \\
\hline $\mathrm{PI}$ & $-->$ & IS & $\underset{* \star}{0.169}$ & $\underset{* \star *}{0.147}$ & $\underset{* \star *}{0.418}$ & $\underset{\star \star}{0.163}$ & $\underset{* * *}{0.265}$ & $\underset{* \star}{0.139}$ & $\begin{array}{l}0.405 \\
* * *\end{array}$ & $\underset{* *}{0.156}$ & $\underset{* \star *}{0.329}$ \\
\hline RA & $-->$ & IS & $\begin{array}{l}0.288 \\
\text { * }\end{array}$ & 0.134 & 0.046 & $\begin{array}{l}0.285 \\
*\end{array}$ & $\begin{array}{l}0.257 \\
*\end{array}$ & $\begin{array}{l}0.344 \\
\star *\end{array}$ & $\prod_{\star \star *}^{0.391}$ & $\begin{array}{l}0.251 \\
*\end{array}$ & 0.170 \\
\hline $\mathrm{CM}$ & $-->$ & IS & ${ }_{* \star *}^{0.323}$ & ${ }_{* \star}^{0.261}$ & $\begin{array}{l}0.205 \\
* \star\end{array}$ & ${ }_{\star \star \star}^{0.313}$ & $\begin{array}{l}0.277 \\
* *\end{array}$ & $\begin{array}{l}0.250 \\
* \star\end{array}$ & $\begin{array}{l}0.170 \\
*\end{array}$ & $\begin{array}{l}0.356 \\
* * *\end{array}$ & $\prod_{* \star *}^{0.434}$ \\
\hline SYQ_SC & $-->$ & IS & & $\begin{array}{l}-0.294 \\
* * *\end{array}$ & & & & & & & \\
\hline SYQ_PI & $-->$ & IS & & & $\begin{array}{l}-0.405 \\
* * \star\end{array}$ & & & & & & \\
\hline SEQ_SC & $-->$ & IS & & & & -0.026 & & & & & \\
\hline SEQ_PI & $-->$ & IS & & & & & -0.163 & & & & \\
\hline RA_SC & $-->$ & IS & & & & & & $\begin{array}{l}-0.220 \\
* * *\end{array}$ & & & \\
\hline RA_PI & $->$ & IS & & & & & & & -0.358 & & \\
\hline CM_SC & $-->$ & IS & & & & & & & & $\begin{array}{l}-0.096 \\
*\end{array}$ & \\
\hline CM_PI & $-->$ & IS & & & & & & & & & -0.245 \\
\hline $\mathrm{R}^{2}$ & & & 0.685 & 0.815 & 0.927 & 0.684 & 0.756 & 0.770 & 0.890 & 0.712 & 0.817 \\
\hline$f^{2}$ & & & & 0.703 & 3.315 & -0.003 & 0.291 & 0.370 & 1.864 & 0.094 & 0.721 \\
\hline
\end{tabular}

Table 2: Results of structural equation model

\begin{tabular}{|c|c|c|c|}
\hline $\begin{array}{l}\text { Hypot } \\
\text { hesis }\end{array}$ & Path & $\begin{array}{l}\text { Path } \\
\text { coefficients }\end{array}$ & Results \\
\hline $\mathrm{H} 1-1$ & Dissatisfaction with system quality-->Intention to switch & -0.003 & Rejected \\
\hline $\mathrm{H} 1-2$ & Dissatisfaction with service quality-->Intention to switch & 0.275 & Rejected \\
\hline $\mathrm{H} 2-1$ & Relative advantage of substitute IT-->Intention to switch & $0.288^{*}$ & Supported \\
\hline $\mathrm{H} 2-2$ & Critical mass-->Intention to switch & $0.323^{* * *}$ & Supported \\
\hline H3-1 & Perceived switching cost-->Intention to switch & $-0.123^{*}$ & Supported \\
\hline H3-2 & Personal innovativeness-->Intention to switch & $0.169^{* *}$ & Supported \\
\hline $\mathrm{H} 4-1$ & $\begin{array}{l}\text { Dissatisfaction with system quality*Perceived switching cost-- } \\
\text { >Intention to switch }\end{array}$ & $-0.294^{* * *}$ & Supported \\
\hline $\mathrm{H} 4-2$ & $\begin{array}{l}\text { Dissatisfaction with service quality*Perceived switching cost-- } \\
\text { >Intention to switch }\end{array}$ & -0.026 & Rejected \\
\hline $\mathrm{H} 4-3$ & $\begin{array}{l}\text { Relative advantage of substitute IT*Perceived switching cost-- } \\
\text { >Intention to switch }\end{array}$ & $-0.220^{* * *}$ & Supported \\
\hline
\end{tabular}

Table 3: Path coefficients and significance 


\begin{tabular}{|l|l|l|l|}
\hline Table 3: continuation & $-0.096^{*}$ & Supported \\
\hline H4-4 & Critical mass*Perceived switching cost-->Intention to switch & $-0.405^{\star * *}$ & $\begin{array}{l}\text { Reversely } \\
\text { Supported }\end{array}$ \\
\hline H5-1 & $\begin{array}{l}\text { Dissatisfaction with system quality*Personal innovativeness-- } \\
\text { Intention to switch }\end{array}$ & $\begin{array}{l}\text { Reversely } \\
\text { Supported }\end{array}$ \\
\hline H5-2 & $\begin{array}{l}\text { Dissatisfaction with service quality*Personal innovativeness-- } \\
\text { Intention to switch }\end{array}$ & $-0.163^{\star * *}$ & $\begin{array}{l}\text { Reversely } \\
\text { Supported }\end{array}$ \\
\hline H5-3 & $\begin{array}{l}\text { Relative advantage of substitute IT*Personal innovativeness-- } \\
\text { H5-4 }\end{array}$ & $-0.358^{* * *}$ & $\begin{array}{l}\text { Reversely } \\
\text { Supported }\end{array}$ \\
\hline
\end{tabular}

${ }^{*} p<.05 .{ }^{* *} p<.01 .{ }^{* \star *} p<.001$.

\section{Discussion and Implications}

Adopting the PPM framework derived from human migration theory, this paper explores the factors influencing users switch from Internet payment to m-payment. The findings and implications are described below.

\subsection{Push Factors}

Push factors comprise dissatisfaction with service quality and dissatisfaction with system quality of Internet payment system, which are regarded to dominate the switching intention to $\mathrm{m}$-payment service. However, to our surprise, hypotheses were not verified in this paper. Neither dissatisfaction on system quality nor dissatisfaction on service quality has influence on intention to switch from Internet payment services to m-payment ones. In other words, users may switch to m-payment not because they are dissatisfied with the system and service quality of the current Internet payment. These results were inconsistent with previous studies which demonstrated that both satisfaction with system quality and service quality had positive effect on users' attitude towards intention [19].

Due to the longer history of Internet payment and popularization of computer, both systems and services were established earlier and more stable than those of $\mathrm{m}$-payment, meeting the current needs of users temporarily. Especially, our respondents are with high education level, and they are more likely to do well in using IT products. As a result, although Internet payment applications have small number of flaws in their systems and services, users with high education level can solve these problems by themselves. Consequently, it may not be a key factor pushing them to switch to m-payment that they are not familiar with. Therefore, we suggested that m-payment providers and investors do not necessary to overemphasize the advantages of their payment systems and services, but create opportunities to familiarize potential users with functions of $m$-payment and encourage them to use it by methods such as cooperation with merchants, services/product publicity, Q\&A, and discount activities with m-payment.

\subsection{Pull Factors}

In this study, pull factors consist of relative advantage of substitute IT and critical mass. Both of them positively affect the intention to switch from Internet payment to m-payment, which is also confirmed in other scholarly studies [2], [20], [77].

Considering the effect of relative advantage of substitute IT, providers should realize that if users gradually notice the superior advantages of $\mathrm{m}$-payment to Internet payment, their intentions to switch will increase relatively. Some promotional activities such as advertising can work in promoting product advantages. Meanwhile, for the effect of critical mass, when individuals plan to use m-payment, possible uncertainty and risk may be the first thing they would consider [15], [34]. In this situation, what they strongly need is the suggestions or influences from users they are familiar with. Thus, we recommend that $\mathrm{m}$-payment service providers and investors pay more attention to retain good relationship with old customers, take advantage of sharing mechanism, and strive to attract opinion leaders or community builders to influence potential users around them by word-of-mouth communication.

\subsection{Mooring Factors}

The mooring factors composed by perceived switching cost and personal innovativeness, which are examined as independent and moderating variables. Firstly, in consistent with previous research (such as [35], [74]), perceived switching cost shows a negative influence on intention to switch, while personal innovativeness shows a positive effect. In this research, switching cost includes monetary and non-monetary costs. Considering the example platforms available in companies such as Alibaba and Tencent in China, they charge extra fee for transferring fund exceeding certain limit (as in Alipay), raising switching cost virtually. We suggest service providers set free trial without limitations for new customers, and enhance m-payment quality to reduce potential risks. Moreover, result implies that innovative individuals present higher positive intention towards m-payment. Thus, service providers should target their customers rapidly and accurately with methods such as data mining analysis, and distinguish 
customer groups based on personal innovativeness. Payment application providers have to periodically insist on innovative designs and functions so as to distinguish themselves from others. Products with new functions would be more attractive to potential individuals with high level of personal innovativeness since product functions can be chosen strategically to affect consumers' responses to innovations.

Secondly, interaction models show that mooring factors can moderate the relationship between independent variables and switching intention. As shown in Table 2, perceived switching cost negatively moderates the relationship between dissatisfaction with system quality and intention to switch, showing the important role that switching costs play. As mentioned before, additional fees are charged in some leading m-payment systems in China This research outcome is a warning to those providers and even others who may intend to start charging. It should be noticed that, however, the switching cost is examined to give a positive influence on the relationship between critical mass and intention to switch. A possible explanation is that for individual who is surrounded by m-payment users, an illusion will be easy to arise that the m-payment has been a most popular payment method in the world. Under the circumstances, one may regard opportunity cost would arise if they stay with the incumbent payment system. Thus, they would be pushed forward to the m-payment system. Personal innovativeness shows negative influences on the relationship between all the push and pull factors and intention to switch, which is opposite to our hypotheses. On the one hand, when unsatisfied with the service and system of incumbent services, users with high personal innovativeness tend to proactively and innovatively solve these issues by their own, instead of immediately giving up the incumbent service. On the other hand, users with high personal innovativeness have a strong sense of self-innovation, and thus they might be eager to explore innovations of a new product by themselves and become opinion leaders who can influence whether people around them switch to the new product. As a result, if suppliers have disclosed their product advantages or most people have generally accepted the product, the switching intention of users with high personal innovativeness might be hindered.

\section{Conclusion and Limitations}

This empirical study focuses on the antecedents affecting users switching intention from Internet payment system to m-payment by drawing upon PPM framework. The results suggest that switching behavior is decided by a cognitive process including push, pull and mooring factors. Several predictors of switching behavior were identified in our study. The pull factors, both relative advantage of substitute IT and critical mass, were examined to positively influence intention to switch. Meanwhile, the push factors, both dissatisfaction with system quality and dissatisfaction with service quality, were not significantly related to switching intention. In addition, for the mooring factors, perceived switching cost showed a negative impact on intention to switch, while personal innovativeness shows a positive influence. Considering moderating effect, the relationship between push factors as well as pull factors and switching behavior could be moderated by perceived switching cost and personal innovativeness.

The current study contributes to the existing literature in several ways. Firstly, this study enables us to understand the reasons of switching behavior from Internet payment to $\mathrm{m}$-payment. Previous research mostly paid attention to the adoption/acceptance or continuous usage with the m-payment system. However, the continuance and switching behaviors of any technologies are not opposite extremes on the same continuum but are driven by different factors. Although customers' switching behaviors have been examined in different contexts [32], [43], [50], less attention was paid to users' switching intention in the context of payment applications. Thus, this paper may address the gap by investigating users' switching behavior from Internet payment to m-payment. Secondly, the PPM framework was extended in the context of m-payment application by identifying specific variables (i.e., switching cost, critical mass, alternative advantage).

In addition, the results also provide practical implications for m-payment service providers. Firstly, if users find that $\mathrm{m}$-payment application possesses considerable advantages, they tend to switch. Therefore, vendors of $\mathrm{m}$-payment application are advised to create and maintain competitive advantages in order to attract new users. For instance, $\mathrm{m}$ payment service providers can provide a better user experience by optimizing the user interface, allowing diversified means of payment (e.g., passwords, fingerprints and face-swiping), simplifying the payment process and so forth. Secondly, compared with the users of other mobile devices, $m$-payment users are more sensitive to switching cost. If users perceive the high switching cost, they are reluctant to switch to $\mathrm{m}$-payment. Thus, for newcomers, in the early period, monetary reward is regarded as an effective way to reduce customers' perceived switching cost and attract potential users in m-payment market. Finally, users with high innovativeness are more likely to switch to m-payment application. Consequently, payment application providers have to periodically need to propose new designs and functions to cater to individuals with high personal innovativeness.

Despite of academic and practical contributions, some limitations should be noted. Firstly, the survey was only conducted in China. Payment culture differs in different countries, which is reflected in the fact that people from different nations show different recognition for Internet payment or $\mathrm{m}$-payment. Future studies should generalize our research results to other cultural backgrounds. Secondly, our sample is with imbalanced gender ratio, and most of the respondents have obtained bachelor's and higher degrees. Future studies will extend the data to explore and compare the influence mechanisms of a wider range of respondent groups. Secondly, the variables need to be further investigated. More relevant variables, such as perceived risks, and privacy risks, should be taken into the research model in further study. 


\section{Acknowledgement}

This study is supported by the National Natural Science Foundation of China (71603151 and 71874167).

\section{References}

[1] R. Agarwal and J. Prasad, A conceptual and operational definition of personal innovativeness in the domain of information technology, Information System Research, vol. 9, no. 2, pp. 204-215, 2017.

[2] I. Ajzen, The theory of planned behavior, Organizational Behavior and Human Decision Process, vol.50, no. 2, pp.179-211, 1991.

[3] H. S. Bansal, S. F. Taylor and Y. S. James, Migrating to new service providers: Towards a unifying framework of consumer's switching behaviors, Journal of the Academy of Marketing Science, vol. 33, no. 1, pp. 95-115, 2005.

[4] H. Baumgartner and C. Homburg, Applications of structural equation modeling in marketing and consumer research: A review, International Journal of Research in Marketing, vol. 13, no. 2, pp. 139-161, 1996.

[5] J. U. Becker, M. Spann and T. Schulze, Implications of minimum contract durations on customers retention, Marketing Letters, vol. 26, no. 4, pp. 579-592, 2015.

[6] D. J. Bogue, Principles of Demography. New York: John Wiley and Scons, Inc.:1-11, 1969.

[7] H. Bouwman, C. Carlsson, P. Walden and et al, Reconsidering the actual and future use of mobile services, Information Systems and E-Business Management, vol. 7, no. 3, pp. 301-317, 2009.

[8] X. F. Cao, L. L. Yu, Z. Y. Liu and et al, Understanding mobile payment users' continuance intention: A trust transfer perspective, Internet Research, vol. 28, no. 2, pp. 456-476, 2018.

[9] I. Chang, C. C. Liu and K. Chen, The push, pull and mooring effects in virtual migration for social networking sites, Information Systems Journal, vol. 24, no. 4, pp. 323-346, 2014.

[10] Y. S. Chang and C. Yang, Why do we blog? From the perspectives of technology acceptance and media choice factors, Behaviour and Information Technology, vol. 32, no. 4, pp. 371-386, 2013.

[11] C. F. Chen and P. C. Chen, Applying the TAM to ravelers' Usage Intentions of GPS Devices, Expert Systems with Applications, vol. 38, no. 5, pp. 6217-6221, 2011.

[12] S. Cheng, S. J. Lee and B. Choi, An empirical investigation of users' voluntary switching intention for mobile personal cloud storage services based on the push-pull-mooring framework, Computers in Human Behavior, vol. 92, pp. 198-215, 2019.

[13] W. H. Chih, K. Y. Wang, L. C. Hsu, and et al, From disconfirmation to switching: An empirical investigation of switching intentions after service failure and recovery, The Service Industries Journal, vol. 32, no. 8, pp. 13051321, 2012.

[14] W. W. Chin, B. L. Marcolin and P. R. Newsted, A partial least squares latent variable modeling approach for measuring interaction effects: results from a Monte Carlo simulation study and an electronic-mail emotion adoption study, Information Systems Research, vol. 14, no. 2, pp. 189-217, 2003.

[15] J. S. Chiou and C. C. Shen, The antecedents of online financial service adoption: The impact of physical banking services on internet banking acceptance, Behaviour and Information Technology, vol. 31, no. 9, pp. 859-871, 2012.

[16] H. C. Chiu, M. Lee, Y. C. Hsieh, and et al, Building customer relationships: A comparison across multiple service encounters, Advances in Consumer Research, vol. 34, pp. 720-725, 2006.

[17] T. Dahlberg, J. Guo and J. Ondrus, A critical review of mobile payment research, Electronic Commerce Research and Applications, vol. 14, no. 5, pp. 265-284, 2015.

[18] S. D'Alessandro and L. Johnson, D. Gray and et al, Customer satisfaction versus churn in the case of upgrades of $3 G$ to $4 G$ cell networks, Marketing Letters, vol. 26, no. 4, pp. 489-500, 2015.

[19] W. H. DeLone and E. R. McLean, Measuring e-commerce success: Applying the DeLone and McLean information systems success model, International Journal of Electronic Commerce, vol. 9, no. 1, pp. 31-47, 2004.

[20] T. Dierkes, M. Bichler and R. Krishnan, Estimating the effect of word of mouth on churn and cross-buying in the mobile phone market with Markov logic networks, Decision Support Systems, vol. 51, no. 3, pp. 361-371, 2011.

[21] L. Fan and Y. H. Suh, Why do users switch to a disruptive technology? An empirical study based on expectation-disconfirmation theory, Information and Management, vol. 51, no. 2, pp. 240-248, 2014.

[22] D. D. Fehrenbacher, Perceptions of information quality dimensions from the perspective of commodity theory, Behaviour and Information Technology, vol. 35, no. 4, pp. 254-267, 2016.

[23] C. Fornell and D. F. Larcker, Structural equation models with unobservable variables and measurement error: Algebra and statistics, Journal of Marketing Research, vol. 18, no.3, pp. 382-388, 1981

[24] B. Furneaux and M. Wade, An exploration of organizational level Information systems discontinuance intentions, MIS Quarterly, vol. 35, no. 3, pp. 573-598, 2011.

[25] L. Gao and K. A. Waechter, Examining the role of initial trust in user adoption of mobile payment services: An empirical investigation, Information Systems Frontiers, vol. 19, no. 3, pp. 525-548, 2017. 
[26] X. Gong, K. Z. K. Zhang, C. Y. Chen, C. M. K. Cheung, and M. K. O. Lee. What drives trust transfer from Web to mobile payment services? The dual effects of perceived entitativity. Information and Management (in press), 2019.

[27] X. Gong, K. Z. K. Zhang, C. Y. Chen, C. M. K. Cheung, and M. K. O. Lee. Transition from web to mobile payment services: The triple effects of status quo inertia. International Journal of Information Management, vol. 50, pp. 310-324, 2020.

[28] J. F. Hair, R. E. Anderson, R. L. Tatham, and et al., Multivariate data analysis with reading (4th ed). Englewood Cliffs, NJ: Prentice Hall, 1995.

[29] X. He and D. Reiner, Why do more British consumers not switch energy suppliers? The role of individual attitudes, The Energy Journal, vol. 38, no. 1, pp. 33, 2017.

[30] C. Y. Hou, and C. C. Chern, The effect of switching costs for corporate antivirus package switching decision, in Proceedings of Pacific Asia Conference in Information system, Auckland, 2007.

[31] A. C. Y. Hou, C. C. Chern, H. G. Chen, and et al, 'Migration to a new virtual world': Exploring MMORPG switching through human migration theory, Computers in Human Behavior, vol. 27, no. 5, pp. 1892-1903, 2011.

[32] J. K. Hsieh, Y. C. Hsieh, H. C. Chiu and et al, Post-adoption switching behavior for online service substitutes: A perspective of the Push-Pull-Mooring framework, Computers in Human Behavior, vol. 28, no. 5, pp. 1912-1920 2012.

[33] S. Y. Hung, C. Y. Ku and C. M. Chang, Critical factors of WAP services adoption: and empirical study, Electronic Commerce Research and Applications, vol. 2, no. 1, pp. 42-60, 2003.

[34] I. J. Hwang, B. G. Lee and K. Y. Kim, Information asymmetry, social networking site word of mouth, and mobility effects on social commerce in Korea, CyberPsychology and Behavior, vol. 17, no. 2, pp. 117-124, 2014

[35] J. D. Jackson, M. Y. Yi and J. S. Park, An empirical test of three mediation models for the relationship between personal innovativeness and user acceptance of technology, Information \& Management, vol. 50, no. 4, pp. 154-161, 2013.

[36] V. L. Johnson, A. Kiser, R. Washington, and et al, Limitations to the rapid adoption of M-payment services: Understanding the impact of privacy risk on M-Payment services, Computers in Human Behavior, vol. 79, pp. 111-122, 2018

[37] M. A. Jones, D. L. Mothersbaugh and S. E. Beatty, Why customers stay: Measuring the underlying dimensions of services switching costs and managing their differential strategic outcomes, Journal of Business Research, vol. 55, no. 6, pp. 441-450, 2002.

[38] M. A. Jones, K. E. Reynolds, D. L. Mothersbaugh, and et al, The positive and negative effects of switching costs on relational outcomes, Journal of Service Research, vol. 9, no. 4, pp. 335-355, 2007.

[39] J. Khalilzadeh, A. B. Ozturk, and A. Bilgihan, Security-related factors in extended UTAUT model for NFC based mobile payment in the restaurant industry, Computers in Human Behavior, vol. 70, pp. 460-474, 2017.

[40] M. Kim, S. Kim, and J. Kim, Can mobile and biometric payments replace cards in the Korean offline payments market? Consumer preference analysis for payment systems using a discrete choice model, Telematics and Informatics, vol. 38, pp. 46-58, 2019.

[41] C. Kim, M. Mirusmonov and I. Lee, An empirical examination of factors influencing the intention to use mobile payment, Computers in Human Behavior, vol. 26, no. 3, pp. 310-322, 2010.

[42] G. Kim, B. Shinb and H. G. Lee, A study of factors that affect user intentions toward email service switching, Information and Management, vol. 43, no. 7, pp. 884-893, 2006.

[43] J. Y. Lai, S. Debbarma and K. R. Ulhas, An empirical study of customer switching behavior towards mobile shopping: A Push-Pull-Mooring model, International Journal of Mobile Communications, vol. 10, no. 4, pp. 386404, 2012.

[44] J.-Y. Lai and J. Wang, Switching attitudes of Taiwanese middle-aged and elderly patients toward cloud healthcare services: An exploratory study, Technological Forecasting and Social Change, vol. 92, pp. 155-167, 2015.

[45] E. S. Lee, A theory of migration, Demography, vol. 3, no. 1, pp. 47-57, 1966.

[46] C. C. Liao, C. C. Liu, Y. P. Liu, and et al, Applying the expectancy disconfirmation and regret theories to online consumer behavior, CyberPsychology, Behavior and Social Networking, vol. 1, no. 4, pp. 241-246, 2011.

[47] F. Liébana-Cabanillas and J. Lara-Rubio, Predictive and explanatory modeling regarding adoption of mobile payment systems, Technological Forecasting and Social Change, vol. 120, pp. 32-40, 2017.

[48] F. Liébana-Cabanillas, F. Muňoz-Leiva and J. Sánchez-Fernández, A global approach to the analysis of user behavior in mobile payment systems in the new electronic environment, Service Business, vol. 12, no. 1, pp. 25-64, 2018.

[49] F. Liébana-Cabanillas, J. Sánchez-Fernández and F. Muñoz-Leiva, Antecedents of the adoption of the new mobile payment systems: The moderating effect of age, Computers in Human Behavior, vol. 35, pp. 464-478, 2014.

[50] T.-C. Lin, T.-C. Cheng, T.-C. Wang, and et al, A study of online auction sellers' intention to switch platform: The case of Yahoo! Kimo versus Ruten_eBay, Decision Sciences, vol. 43, no. 2, pp. 241-272, 2012.

[51] J. Lu, J. Wei, C. S. Yu, and et al, How do post-usage factors and espoused cultural values impact mobile payment continuation? Behaviour and Information Technology, vol. 36, no. 2, pp. 140-164, 2017.

[52] Y. Lu, S. Yang, P. Y. K. Chau, and et al, Dynamics between the trust transfer process and intention to use mobile payment services: A cross-environment perspective, Information and Management, vol. 48, no. 8, pp. 393-403, 2011. 
[53] H. Luo, W. Luo and D. Strong, Perceived critical mass effect on groupware acceptance, European Journal of Information Systems, vol. 9, no. 2, pp. 91-103, 2000.

[54] C. Maier, C. Laumer, C. Weinert and et al, The effects of technostress and switching stress on discontinued use of social networking services: a study of Facebook use, Information Systems Journal, vol. 25, no. 3, pp. 275-308, 2015.

[55] N. Mallat, Exploring consumer adoption of mobile payments-a qualitative study, The Journal of Strategic Information Systems, vol. 16, no. 4, pp. 413-432, 2007.

[56] D. F. Midgley and G. R. Dowling, Innovativeness: The concept and its measurement, Journal of Customer Research, vol. 4, no. 4, pp. 229-242, 1978

[57] H. A. Mohammadi, Study of mobile banking loyalty in Iran, Computers in Human Behavior, vol. 44, pp. 35-47, 2015.

[58] B. Moon, Paradigms in migration research: Exploring moorings' as a schema, Progress in Human Geography, vol. 19, no. 4, pp. 504-524, 1995.

[59] Nielsen. (2016). Nielsen Survey Data: China holds the highest proportion in mobile payment use. Zhicheng [Online]. Available: http://www.zhicheng.com/n/20161123/108247.html.

[60] T. Oliveira, M. Thomas, G. Baptista, and et al, Mobile payment: Understanding the determinants of customer adoption and intention to recommend the technology, Computers in Human Behavior, vol. 61, pp. 404-414, 2016.

[61] P. Y. Pai and H. T. Tasi, How virtual community participation influences consumer loyalty intentions in online shopping contexts: An investigation of mediating factors, Behaviour and Information Technology, vol. 30, no. 5, pp. 603-615, 2011

[62] R. Rauniar, G. Rawski, J. Yang, and et al, Technology acceptance model (TAM) and social media usage: An empirical study on Facebook, Journal of Enterprise Information Management, vol. 27, no. 1, pp. 6-30, 2014

[63] E. G. Ravenstein, The laws of migration, Journal of the Statistic Society, vol. 48, no. 2, pp. 167-235, 1885

[64] P. G. Schierz, O. Schilke and B. W. Wirtz. Understanding consumer acceptance of mobile payment services: an empirical analysis. Electronic Commerce and Research Applications, vol. 9, pp. 209-216, 2010

[65] E. L. Slade, M. D. Williams and Y. K. Dwivedi, Mobile payment adoption: Classification and review of the extant literature, Marketing Review, vol. 13, no. 2, pp. 167-190, 2013.

[66] G. W. H. Tan, K. B. Ooi, S. C. Chong, and et al, NFC mobile credit card: The next frontier of mobile payment, Telematics and Informatics, vol. 31, no. 2, pp. 292-307, 2014

[67] W. K. Tan and M. S. Sie, The impact of personal innovativeness on product aesthetics and self-connection with brand: A case study of mobile phone users, Behaviour and Information Technology, vol. 34, no. 3, pp. 316-325, 2015

[68] C. W. Tsou, Consumer acceptance of Windows 7 and Office 2010 - The moderating effect of personal innovativeness, Journal of Research and Practice in Information Technology, vol. 44, no. 1, pp. 59-80, 2012.

[69] P. Turnbull, S. Leek and G. Ying, Customer confusion: the mobile phone market, Journal of Marketing Management, vol.16, no.1-3, pp.143-163, 2000

[70] L. Wang, X. Luo, X. Yang, and et al, Easy come or easy go? Empirical evidence on switching behaviors in mobile payment applications, Information \& Management, vol. 56, no. 7, pp. 103-150, 2019.

[71] Z. L. Wen, K. - T. Hau, W. M. Herbert. Structural equation model testing: cutoff criteria for goodness of fit indices and chi-square test. Acta Psychologica Sinica, vol. 36, no. 2, pp. 186-194, 2004

[72] Y. L. Wu, Y. H. Tao, C. P. Li, and et al, User-switching behavior in social network sites: A model perspective with drill-down analyses, Computers in Human Behavior, vol. 33, pp. 92-103, 2014.

[73] J. H. Wu and S. C. Wang, What drives mobile commerce? An empirical evaluation of the revised technology acceptance model, Information and Management, vol. 42, no. 5, pp. 719-729, 2005.

[74] S. Yang, Y. Lu, S. Gupta, and et al, Mobile payment services adoption across time: An empirical study of the effects of behavioral beliefs, social influences, and personal traits, Computers in Human Behavior, vol. 28, no. 1 , pp. 129-142, 2012.

[75] C. Ye and R. Potter, The role of habit in post-adoption switching of personal information technologies: An empirical investigation, Communications of the Association for Information Systems, vol. 28, pp. 585-610, 2011

[76] T. K. Yu and K. Fang, Measuring the post-adoption customer perception of mobile banking services, CyberPsychology and Behavior, vol. 12, no. 1, pp. 33-35, 2009.

[77] K. Z. K. Zhang, M. K. O. Lee, C. M. C. Cheung, and et al, Understanding the role of gender in bloggers' switching behavior, Decision Support System, vol. 47, no. 4, pp. 540-546, 2009.

[78] T. Zhou, An empirical examination of initial trust in mobile payment, Wireless Personal Communications, vol. 77, no. 2, pp. 1519-1531, 2014.

[79] T. Zhou, An empirical examination of continuance intention of mobile payment services, Decision Support System, vol. 54, no. 2, pp. 1085-1091, 2013

[80] T. Zhou, An empirical examination of users' switch from online payment to mobile payment. International Journal of Technology and Human Interaction, vol. 11, no. 1, pp. 55-66, 2015 


\section{Appendix A: Convergent Validity Analysis and Reliability Analysis}

\begin{tabular}{|c|c|c|c|c|c|}
\hline Factor & $\begin{array}{l}\text { Ite } \\
\mathrm{ms}\end{array}$ & Description & $\mathrm{FL}$ & $\mathrm{CR}$ & AVE \\
\hline \multirow{4}{*}{$\begin{array}{l}\text { Dissatisfacti } \\
\text { on with } \\
\text { system } \\
\text { quality } \\
\text { (SYQ) }\end{array}$} & SYQ1 & $\begin{array}{l}\text { Compared to m-payment, the user interface of Internet } \\
\text { payment is badly designed. }\end{array}$ & 0.765 & \multirow{4}{*}{0.877} & \multirow{4}{*}{0.640} \\
\hline & SYQ2 & $\begin{array}{l}\text { Compared to m-payment, Internet payment loads all } \\
\text { the text and graphics less quickly. }\end{array}$ & 0.787 & & \\
\hline & SYQ3 & $\begin{array}{l}\text { Compared to m-payment, Internet payment operation } \\
\text { is more complicated. }\end{array}$ & 0.827 & & \\
\hline & SYQ5 & $\begin{array}{l}\text { Internet payment can't respond to my requests as } \\
\text { quickly as m-payment. }\end{array}$ & 0.817 & & \\
\hline \multirow{4}{*}{$\begin{array}{l}\text { Dissatisfacti } \\
\text { on with } \\
\text { service } \\
\text { quality } \\
\text { (SEQ) } \\
\end{array}$} & SEQ1 & $\begin{array}{l}\text { I feel uncomfortable using the functions and services } \\
\text { provided by Internet payment. }\end{array}$ & 0.866 & \multirow{4}{*}{0.853} & \multirow{4}{*}{0.593} \\
\hline & SEQ2 & Internet payment can't provide the services I need. & 0.730 & & \\
\hline & SEQ4 & Internet payment can't meet the specific needs of mine. & 0.732 & & \\
\hline & SEQ5 & Internet payment can't provide the service on time. & 0.743 & & \\
\hline \multirow{4}{*}{$\begin{array}{l}\text { Perceived } \\
\text { switching } \\
\text { cost (SC) }\end{array}$} & SC1 & $\begin{array}{l}\text { It would take a lot of time and effort changing to } \mathrm{m} \text { - } \\
\text { payment system. }\end{array}$ & 0.867 & \multirow{4}{*}{0.907} & \multirow{4}{*}{0.708} \\
\hline & SC2 & $\begin{array}{l}\text { It would take a lot of learning costs towards changing } \\
\text { to m-payment system. }\end{array}$ & 0.848 & & \\
\hline & SC3 & $\begin{array}{l}\text { It would take a lot of related costs towards changing to } \\
\text { m-payment system. }\end{array}$ & 0.828 & & \\
\hline & SC4 & $\begin{array}{l}\text { In general it would be a hassle changing to m-payment } \\
\text { system. }\end{array}$ & 0.822 & & \\
\hline \multirow{3}{*}{$\begin{array}{l}\text { Personal } \\
\text { innovativene } \\
\text { ss (PI) }\end{array}$} & Pl1 & $\begin{array}{l}\text { If I heard about a new information technology, I would } \\
\text { look for ways to experimenting it. }\end{array}$ & 0.750 & \multirow{3}{*}{0.833} & \multirow{3}{*}{0.625} \\
\hline & $\mathrm{PI} 2$ & $\begin{array}{l}\text { Among my peers, I am usually the first to try out new } \\
\text { information technologies. }\end{array}$ & 0.793 & & \\
\hline & $\mathrm{PI} 4$ & I like to experiment with new information technologies. & 0.826 & & \\
\hline \multirow{4}{*}{$\begin{array}{l}\text { Relative } \\
\text { advantage of } \\
\text { substitute IT } \\
\text { (RA) }\end{array}$} & RA1 & $\begin{array}{l}\text { Compared to Internet payment, m-payment is not } \\
\text { limited by time and location. }\end{array}$ & 0.778 & \multirow{4}{*}{0.895} & \multirow{4}{*}{0.684} \\
\hline & RA2 & $\begin{array}{l}\text { Compared to Internet payment, m-payment is more } \\
\text { convenient. }\end{array}$ & 0.893 & & \\
\hline & RA3 & $\begin{array}{l}\text { Compared to Internet payment, m-payment is more } \\
\text { efficient. }\end{array}$ & 0.915 & & \\
\hline & RA4 & $\begin{array}{l}\text { Compared to Internet payment, m-payment is more } \\
\text { effective in managing a payment account. }\end{array}$ & 0.704 & & \\
\hline \multirow{2}{*}{$\begin{array}{l}\text { Critical mass } \\
(\mathrm{CM})\end{array}$} & CM1 & $\begin{array}{l}\text { Most people in my class/office use m-payment } \\
\text { systems. }\end{array}$ & 0.914 & \multirow[t]{2}{*}{0.926} & \multirow[t]{2}{*}{0.862} \\
\hline & $\mathrm{CM} 3$ & Most people in my group use m-payment systems. & 0.943 & & \\
\hline \multirow{3}{*}{$\begin{array}{l}\text { Intention to } \\
\text { switch (IS) }\end{array}$} & IS1 & I have been used to paying by m-payment. & 0.824 & \multirow{3}{*}{0.919} & \multirow{3}{*}{0.791} \\
\hline & IS2 & $\begin{array}{l}\text { I will reduce the usage of Internet payment, and } \\
\text { increase m-payment. }\end{array}$ & 0.905 & & \\
\hline & IS3 & $\begin{array}{l}\text { M-payment is likely to become the primary payment } \\
\text { method of mine in the future. }\end{array}$ & 0.936 & & \\
\hline
\end{tabular}

